\title{
Pemanfaatan Batu Gunung Limbong Kecamatan Rantepao Dalam Campuran Stone Matrix Asphalt Kasar
}

\author{
Chelia Febriyani Timbonga ${ }^{1}$, Alpius ${ }^{\star 2}$, Louise Elizabeth Radjawane ${ }^{* 3}$ \\ *1 Mahasiswa Program Studi Teknik Sipil, Universitas Kristen Indonesia Paulus, Makassar \\ Email febriyanichelia@gmail.com \\ *2 Dosen Program Studi Teknik Sipil, Universitas Kristen Indonesia Paulus, Makassar \\ Email alpiusnini@gmail.com \\ *3 Dosen Program Studi Teknik Sipil, Universitas Kristen Indonesia Paulus, Makassar \\ Email eliz louise@yahoo.com
}

\begin{abstract}
ABSTRAK
Pada penelitian ini menggunakan agregat dari batu Gunung Limbong untuk campuran Stone Matrix Asphalt kasar. Tujuan penelitian untuk mengetahui karakteristik agregat dan komposisi SMA kasar. Hasil dari pengujian Marshall konvensional akan digunakan sebagai acuan dalam penentuan Kadar aspal optimum kemudian akan dibuat lagi benda uji Kadar aspal optimum campuran Stone Matrix Asphalt (SMA) kasar kemudian dilakukan pengujian Marshall Immersion untuk memperoleh nilai Stabilitas Marshall Sisa. Hasil penelitian yang dilakukan di Laboratorium Jalan dan Aspal Fakultas Teknik Jurusan Sipil Universitas Kristen Indonesia Paulus Makassar, menunjukkan bahwa karakteristik bahan perkerasan berupa batu gunung Limbong Kecamatan Rantepao memenuhi Spesifikasi sebagai bahan lapisan perkerasan jalan. Melalui Uji Marshall konvensional diperoleh karakteristik campuran Stone Matrix Asphalt (SMA) kasar dengan kadar aspal 6,00 \% , $6,25 \%, 6,50 \%, 6,75 \%$, dan 7,00 \%. Hasil pengujian Marshall Immersion diperoleh Stabilitas Marshall Sisa sebesar $94,16 \%$ dengan kadar aspal 7,00\% memenuhi persyaratan yaitu > $90 \%$ sesuai dengan Spesifikasi Umum Bina Marga 2018.
\end{abstract}

Kata Kunci: Karakteristik Agregat, Komposisi SMA kasar, Uji Marshall

\begin{abstract}
In this study, using the aggregate from the Mount Limbong stone for a mixture of coarse Stone Matrix Asphalt. The research objective was to determine the aggregate characteristics and composition of the crude SMA. The results showed that the characteristics of the pavement material in the form of Limbong mountain rock, Rantepao District, met the specifications as a road pavement coating material. Through the conventional Marshall test, the characteristics of the mixture of rough Stone Matrix Asphalt (SMA) mixture with asphalt content are 6.00\%, 6.25\%, 6.50\%, 6.75\%, and 7.00\%. Marshall Immersion test results obtained Remaining Marshall Stability of $94.16 \%$ with asphalt content of $7.00 \%$ fulfilling the requirements, namely $>90 \%$ in accordance with the General Specifications of Bina Marga 2018.
\end{abstract}

Keywords: Aggregate Characteristics, Coarse SMA Composition, Marshall Test

\section{PENDAHULUAN}

Toraja Utara merupakan salah satu daerah dataran tinggi di Provinsi Sulawesi Selatan yang berpotensi besar dalam pengembangan pariwisata di Indonesia yang didukung oleh keindahan alam dan budaya khas daerah setempat. Potensi tersebut menjadi salah satu alasan untuk meningkatkan pembangunan jalan raya. Suatu perkerasan jalan sangat bergantung pada kebutuhan terhadap agregat sehingga untuk mencukupi kebutuhan agregat tersebut maka harus dilakukan pemanfaatan sumber daya alam sekitar secara maksimal untuk meminimalisir biaya mendatangkan agregat dari luar. Lembang Limbong yang terletak di kecamatan Rantepao kabupaten Toraja Utara dengan ketinggian \pm 940meter dari permukaan laut (mdpl) memiliki kekayaan alam berupa batu gunung yang merupakan batuan yang mengandung kapur dan bisa digunakan sebagai material dalam perkerasan jalan. Saat ini, selain digunakan sebagai material dalam perkerasan jalan, batu gunung Limbong juga digunakan oleh masyarakat setempat untuk membuat pondasi bangunan.

Stone Matrix Asphalt (SMA), adalah beton aspal dengan campuran panas yang terdiri dari agregat dari agregat kasar, agregat halus, bahan pengisi dan bahan pengikat (aspal). Pada lapis perkerasan lentur, SMA digunakan sebagai lapis permukaan perkerasan jalan dengan susunan agregat yang 
bergradasi terbuka (Open graded) atau biasa juga disebut dengan gradasi seragam yang artinya kandungan agregat halusnya sedikit sehingga terdapat lebih banyak rongga-rongga atau ruang antar agregat yang kosong. Pada lapisan permukaan terdapat lapis aus dan lapis antara dan lapis pondasi dimana Stone Matrix Asphalt sebagai lapis aus terletak diatas lapis antara.

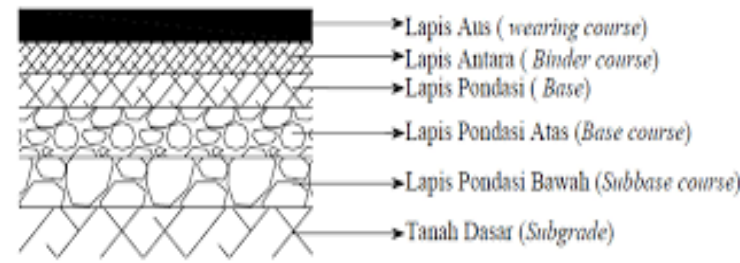

\section{Gambar 1. Susunan lapisan perkerasan}

Stone Matrix Asphalt (SMA) mengandalkan kekuatan dari rangka (skeleton) agregat kasar, dan rongga diantaranya diisi dengan mastik, yaitu campuran antara agregat halus, bahan pengisi dan aspal dengan kadar relatif tinggi untuk memberikan durabilitas yang baik. (Sumber: Nyoman Swaryana, 2015).

Penggunaan agregat kasar dengan jumlah fraksi yang tinggi akan mengakibatkan agregat saling mengunci sehingga biasa menghasilkan campuran beraspal yang tahan terhadap rutting (Roberts et. Al., 1996).

Pengunaan Stone Matrix Asphalt antara lain pada jalaln yang memiliki beban lalu lintas yang berat, persimpangn, jalan yang memiliki kondisi kemiringan yang berjenjang (tanjakan, penurunan, dan tikungan tajam), terkhusus untuk lapis permukaan yang mengalami tekanan roda kendaraan secara berlebihan

Stone Matrix Asphalt (SMA) adalah suatu lapisan permukaan tipis, mempunyai ketahanan yang baik terhadap alur (rutting) dan mempunyai durabilitas yang tinggi, sehingga SMA cocok digunakan untuk lapisan permukaan jalan berlalu lintas berat, walaupun dapat juga digunakan untuk semua jenis perkerasan jalan (Wonson, 1996).

Pada campuran Stone Matrix Asphalt (SMA) Material yang digunakan antara lain adalah agregat kasar, agregat halus, filler (semen) dan bahan pengikat (aspal).

Fraksi agregat kasar yang tertahan pada saringan No.4 $(4.57 \mathrm{~mm})$ ialah fraksi agregat yang diperlukan untuk rancangan campuran dan dilakukan dalam kondisi basah dan harus dalam keadaan bersih atau didalamnya tidak teradapat lempung atau bahan lain yang tidak dikehendaki, keras, dan awet.
Agregat halus ialah batu pecah atau pasir yang terahan pada yang saringan No. 200 dan lolos dari saringan No. $4(4,75 \mathrm{~mm})$. Syarat agregat halus yang akan digunakan agar memenuhi Spesifikasi Umum Bina Marga terkhusus untuk pasal (6.3.2.1) harus dalam keadaan bersih atau didalamnya tidak teradapat lempung atau bahan lain yang tidak dikehendaki, keras, dan awet serta diperoleh dari batu yang sesuai dengan syarat mutu. Agregat halus berfungsi untuk menambah stabilitas dari suatu campuran karena sifat saling mengunci antar agregat kasar menjadi lebih kokoh dengan adanya agregat halus yang mengisi rongga antar agregat kasar.

Agregat yang lebih halus lagi dari agregat halus disebut dengan Filler yang memiliki fungsi sebagai pengisi rongga, mengurangi permeabilitas dan meningkatkan kekuatan tarik campuran beton aspal. Filler atau bahan pengisi antara lain berupa debu batu kapur, debu kapur padam dan debu kapur magnesium yang memenuhi persyaratan AASTHO M303-89(2014). Selain itu diperbolehkan juga semen atau bartu terbang tipe $\mathrm{C}$ dan tipe $\mathrm{F}$ dengan persetujuan Pengawas Pekerjaan. Terkhusus untuk campuran beraspal panas dengan penggunaan aspal keras penetasi 60/70 sebagai bahan pengikatnya diperbolehkan menggunakan semen sebagai bahan pengisinya. Filler memiliki persyaratan antara lain kering, tidak menggupal dan lolos ayakan No.200 (75 micron) lebih dari 75\% terhadap beratnya.

Aspal adalah material yang apabila terjadi peningkatan temperature akan dan apabila temperaturnya berkurang akan mengental. Sifat ini disebut kepekaan terhadap adanya perubahan temperature oleh bahan kimiawi yang terkandung dalam sekalipun nilai penetrasi atau viskositas pada temperatur tertentu sama. Aspal beserta agregat merupakan materia yang membentuk campuran perkerasan jalan (Sukirman,2003). Aspal memiliki sifat yang padat dengan warna hitam atau cokelat, memiliki daya lekat, mengandung hidrokarbon sebagai bagian utamanya yang merupakan hasil dari minyak bumi atau larutan karbondisulfida (Wignall,2003).

Spesifikasi Umum Bina Marga 2018 menjadi landasan atau acuan penelitian ini.

Stone Mastic Asphalt (SMA) telah diteliti oleh beberapa peneliti sebelumnya antara lain Hafis Mustofa (2016), melakukan penelitian tentang Pengujian Campuran Bergradasi Stone Mastic Asphalt (SMA) Menggunakan Bahan Reclaimed Asphalt Pavement dan Limbah Arang Batubara. Nyoman Suaryana (2015), melakukan penelitian tentang Evaluasi Stabilitas Dinamis dan Flow Number sebagai Parameter Ketahan ketahanan Campuran Beraspal Terhadap Deformasi Permanen. Novita Pradani, Joy Fredi Batti (2018), 
meneliti tentang Pengaruh Penggunaan Bahan Tambah Viatop Pada Campuran Stone Mastic Asphalt Terhadap Titik Lembek Aspal dan Sifat Draindrown Campuran. Anas Tahir, Mashuri, Syamsul Arifin (2019), meneliti tentang Karakteristik Draindown Campuran Stone Matrix Asphalt (SMA) yang Menggunakan Filler Abu-Batu dan Semen. Teguh Kurniawan,Zulkifli Lubis (2019),meneliti tentang Alternatif Penggunaan Serat Eceng Gondok pada Campuran Stone Matrix Asphalt Gradasi Halus Meningkatkan Stabilitas Campuran Aspal Panas.

Tujuan dari penelitian ini adalah Mengetahui karakteristik agregat, aspal dan berat jenis filler (semen), mengetahui komposisi dan karakteristik campuran SMA Kasar melalui pengujian Marshall konvensional dan Stabilitas Marshall Sisa melalui pengujian Marshall immersion.

\section{METODE}

Material yang berupa agregat dari batu gunung diambil dari lokasi yang terletak di Lembang Limbong, kecamatan Rantepao, Kabupaten Toraja Utara yang berjarak $\pm 2 \mathrm{~km}$ pusat kota Rantepao dan dapat dicapai baik dengan sepeda motor maupun mobil dengan waktu tempuh sekitar 10-15 menit. Waktu yang diperlukan oleh peneliti untuk melakukan penelitian yaitu kurang lebih 1 (satu bulan) sejak tanggal 22 Juni 2020. Jalan menuju lokasi pengambilan material menggunakan jenis perkerasan kaku. Pengambilan agregat dilakukan secara manual sebanyak $\pm 40 \mathrm{~kg}$ menggunakan sekop dan dimasukkan ke dalam karung.

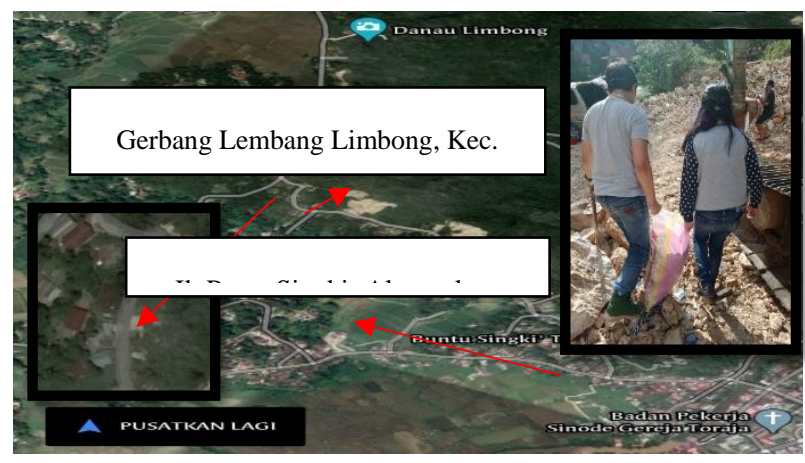

Gambar 2. Lokasi pengambilan material

\section{Pemeriksaan Karakteristik Agregat}

Pemeriksaan karakteristik agregat dilakukan terhadap Abrasi dengan Mesin Los Angeles (SNI 2417:2008) dengan maksud dari pengujian ini yaitu mengetahui keausan dari agregat karena beberapa faktor mekanis. Keausan (\%) ialah hasil bagi berat benda yang aus (lolos saringan No.12) terhadap berat total.

Pemeriksaan Berat Jenis dan Penyerapan Air Agregat Kasar (SNI 1969 - 2016), pemeriksaan ini bertujuan untuk mengelompokkan agregat kasar dengan tolak ukur nilai berat jenis dan penyerapan agrgat kasar.

Pemeriksaan Berat Jenis dan Penyerapan Air Agregat Halus (SNI 1970 - 2016), pemeriksaan ini bertujuan untuk mengelompokkan agregat halus dengan tolak ukur nilai berat jenis dan penyerapan agrgat halus.

Pemeriksaan Analisa Saringan (SNI ASTM C136:2012), tujuan dilakukan analisa saringan yaitu untuk mendapatkan gradasi yang sesuai dengan spesifikasi standar untuk campuran Stone Matrix Asphalt (SMA) Kasar menggunakan saringan.

Pemeriksaan Material Lolos Ayakan No.200 (SNI ASTM C117: 2012) dengan tujuan pengujian yaitu dilakukan untuk mengukur presentase bahan dalam agregat yang lolos saringan No.200

Pemeriksaan Nilai Setara Pasir (SNI 03 - 4428 1997), dengan maksud untuk mengetahui presentase Nilai setara pasir yang terkandung dalam agregat halus.

Pemeriksaan Partikel Pipih dan Lonjong (ASTM D479-0, dengan tujuan untuk menentukan indeks kepipihan dan kelonjongan (\%) agregat yang akan digunakan dalam campuran beraspal.

Pemeriksaan Kelekatan Agregat Terhadap Aspal (SNI 2439 - 2011), pemeriksaan ini dilakukan secara visual dengan tujuan mengukur angka kelekatan agregat terhadap aspal yang dinyatakan dalam persen (\%).

\section{Pemeriksaan Berat Jenis Filler}

Pemeriksaan Berat Jenis Filler (SNI 03-1969-1990), dilakukan untuk mengetahui berat jenis Filler berupa semen.

\section{Pemeriksaan Karakteristik Aspal}

Pemeriksaan karakteristik aspal yang ialah antara lain adalah pengujian Penetrasi pada $25^{\circ} \mathrm{C}$ (SNI 2456 - 2011) dilakukan untuk mengetahui tingkat dari kekerasan aspal dengan cara mengukur seberapa dalam sabuah jarum yang menancap pada aspal dengan beban tertentu pada suhu $25^{\circ}$.

Pemeriksaan Titik Lembek $\left({ }^{\circ} \mathrm{C}\right)$ (SNI 2434 - 2011) dilakukan untuk mengetahui pada suhu berapa aspal mulai lembek.

Pemeriksaan Titik Nyala $\left({ }^{\circ} \mathrm{C}\right)$ (SNI 2433 - 2011), dilakukan untuk mengetahui pada suhu berapa timbulnya nyala pada bagian permukaan aspal.

Pemeriksaan Berat yang Hilang (SNI - 06 - 2441 1991), dilakukan untuk mengetahui kehilangan minyak pada aspal yang oleh pemanasan secara ulang dengan tujuan mengetahui perubahan kinerja aspal yang diakibatkan.

Pengujian Penetrasi Thin Fim Oven Test (SNI 2456 - 2011) pengujian ini dilakukan untuk mengetahui 
tingkat kekerasan aspal dengan cara mengukur seberapa dalam sabuah jarum yang menancap pada aspal dengan beban tertentu pada suhu $25^{\circ}$ setelah pengujisn residu hasil TFOT

Pemeriksaan Daktilitas pada $25^{\circ}$ C (SNI 2432 2011) pengujian ini dinyatakan sebagai panjang pemuluran aspal yang dapat dicapai hingga sebelum putus dengan tujuan untuk mengetahui kekenyalan aspal.

PemeriksaanBerat Jenis (SNI 2441 - 2011) dengan maksud dilakukan pemeriksaan ini ialah untuk mengetahui berat jenis aspal terhadap air suling.
Perancangan campuran Stone Matrix Asphalt menggunakan metode grafis dan analitis yaitu melalui tabel spesifikasi ukuran butir (gradasi) yang lolos saringan. Gradasi campuran ditentukan oleh nilai tengah dari batasan-batasan spesifikasi gradasi yang telah ditentukan. Komposisi campuran Stone Matrix Asphalt menggunakan campuran aspal panas (Hot mix) dengan ukuran maksimum partikel dari campuran Stone Matrix Asphalt kasar adalah $19 \mathrm{~mm}$. Komposisi rancangan agregat yang akan digunakan dalam campuran Stone Matrix Asphalt kasar pada penelitian ini dapat dilihat pada Tabel 1.

\section{Perancangan Campuran}

Tabel 1. Gradasi agregat SMA kasar

\begin{tabular}{|c|c|c|c|c|c|}
\hline \multicolumn{2}{|c|}{ Ukuran saringan } & \multicolumn{4}{|c|}{ Lolos Saringan } \\
\hline Inchi & $\mathrm{Mm}$ & & Spesifikasi (\%) & & Gradasi Campuran (\%) \\
\hline $1 \frac{1}{2 \prime \prime}$ & 37.5 & & & & \\
\hline 1" & 25 & & 100 & & \\
\hline $3 / 4 "$ & 19 & 90 & - & 100 & 95 \\
\hline 1/2" & 12.5 & 50 & - & 88 & 69 \\
\hline $3 / 8 "$ & 9.5 & 25 & - & 60 & 42,5 \\
\hline No.4 & 4.75 & 20 & - & 28 & 24 \\
\hline No.8 & 2.36 & 16 & - & 24 & 20 \\
\hline No.16 & 1.18 & & - & & \\
\hline No.30 & 0.6 & & - & & \\
\hline No.50 & 0.3 & & - & & \\
\hline No.100 & 0.15 & & - & & \\
\hline No.200 & 0.075 & 8 & - & 11 & 9,5 \\
\hline
\end{tabular}

\section{Komposisi campuran}

Rancangan komposisi campuran Stone Matrix Asphalt (SMA) Kasar memiliki komposisi agregat kasar, komposisi agregat halus dan komposisi filler (semen) yang berbeda-beda untuk kadar aspal dalam campuran yang berbeda-beda pula, namun komposisi total campuran atau berat total campuran sama untuk semua kadar aspal yaitu $100 \%$ dan 1200 gr. Kadar aspal yang dimaksud yaitu mulai dari $6,00 \%-7,00 \%$ dengan kenaikan $0,25 \%$ sesuai dengan Spesifikasi Umum Bina Marga 2018.Komposisi agregat kasar, agregat halus, dan filler untuk kadar aspal $6 \%$ masing-masing adalah $72,57 \%, 12,79 \%$ dan $8,64 \%$. Komposisi agregat kasar, agregat halus, dan filler untuk kadar aspal $6,25 \%$ masing-masing adalah $72,43 \%, 12,71 \%$ dan $8,61 \%$. Komposisi agregat kasar, agregat halus, dan filler untuk kadar aspal 6,5\% masing-masing adalah $72,29 \%, 12,64 \%$ dan 8,57 \%. Komposisi agregat kasar, agregat halus, dan filler untuk kadar aspal 6,75\% masing-masing adalah 72,14\%, 12,57 $\%$ dan $8,54 \%$. Komposisi agregat kasar, agregat halus, dan filler untuk kadar aspal $7 \%$ masingmasing adalah $72,00 \%, 12,50 \%$ dan $8,50 \%$.
Jumlah benda uji yang dibuat dalam penelitian ini dapat dilihat pada tabel 2 .

Tabel 2. Jumlah Benda Uji campuran Stone Matrix Asphalt (SMA) Kasar

\begin{tabular}{cccc}
\hline \multicolumn{4}{c}{ Stone Matrix Asphalt (SMA) } \\
\hline No. & $\begin{array}{c}\text { Kadar } \\
\text { Aspal } \\
(\%)\end{array}$ & $\begin{array}{c}\text { Pengujian } \\
\text { Marshall } \\
\text { Konvensional }\end{array}$ & $\begin{array}{c}\text { Pengujian } \\
\text { Marshall } \\
\text { Immersion }\end{array}$ \\
\hline 1 & 6,00 & 3 & \\
2 & 6,25 & 3 & \\
3 & 6,50 & 3 & \\
4 & 6,75 & 3 & 3 \\
5 & 7,00 & 3 & 3 \\
\hline
\end{tabular}

\section{Pengujian Marshall Konvensional}

Jumlah benda uji campuran Stone Matrix Asphalt (SMA) Kasar untuk pengujian Marshall Konvensional yaitu sebanyak 15 buah dengan masing-masing 3 benda uji untuk setiap kadar aspal. Pengujian Marshall dilakukan untuk mengukur ketahanan (stabilitas) campuran 
beraspal terhadap kelelehan plastis (flow). Daya tahan atau ketahanan adalah beban yang paling maksimum yang mampu dipikul oleh campuran sebelum terjadi kelelehan plstis (flow), sedangkan flow adalah perubahan bentuk campuran aspal berupa deformasi atau regangan mulai dari tanpa adanya beban sampai dengan beban maksimum. Pengujian Marshall mengacu pada prosedur SNI06-2489-1991.

\section{Penentuan Kadar Aspal Optimum}

Penentuan KAO diperoleh melalui perhitungan setelah pengujian Marshall Konvensional sebanyak 15 buah benda uji. Data-data yang diperoleh dari 15 benda uji tersebut dmasukkan kedalam tabel $\mathrm{Hot}$ Mix Desain metode Marshall untuk memperoleh nilai stabilitas, flow, nilai kepadatan campuran dan kepadatan agregat. KAO ditentukan oleh nilai rataan paling tinggi dari grafik hubungan stabilitas dan kepadatan campuran yang dipadatkan dengan kadar aspal. Untuk campuran SMA Kasar, kadar aspal optimum ditentukan berdasarkan campuran yang memenuhi standar spesifikasi dan memiliki nilai volumetric campuran dalam rongga (VIM) terkecil.

\section{Pengujian Marshall Immersion}

Pembuatan benda uji campuran Stone Matrix Asphalt (SMA) Kasar untuk pengujian Marshall Immersion yaitu sebanyak 3 buah dengan komposisi campuran berdasarkan campuran dengan kadar aspal optimum yaitu 7,00\% karena memiliki nilai VIM terendah. Marshall Immersion bertujuan untuk mengetahui Stabilitas Marshall Sisa yaitu perbandingan antara benda uji Marshall yang direndam selama 24 jam dengan suhu $60^{\circ} \mathrm{C}$ dengan benda uji Marshall yang direndam selama 0,5 jam suhu dengan $60^{\circ} \mathrm{C}$. Stabilitas Marshall Sisa menunjukkan perilaku kelekatan antar butir agregat dengan aspal didalam campuran.

\section{HASIL DAN PEMBAHASAN}

\section{Analisis Karakteristik Material}

\section{Agregat}

Melalui pengujian keausan dengan Los Angeles diperoleh hasil dengan nilai ketahanan agregat kasar terhadap keausan dari fraksi $\mathrm{A}$ ialah 5,36\%, fraksi B ialah 5,28\%, fraksi C ialah 3,76\% dan fraksi D ialah $5,04 \%$. Setiap fraksi yang telah dilakukan pengujian tidak melebihi nilai maksimum yaitu $30 \%$ sesuai dengan standar acuan atau persyaratan Spesifiasi Umum Bina Marga 2018. Dengan demikian, agregat dari batu Gunung Limbong Kecamatan Rantepao Kabupaten Toraja Utara memenuhi syarat penggunaan sebagai bahan untuk lapisan permukaan jalan karena tahan terhadap keausan akibat gesekan antar agregat maupun agregat dengan roda/ban kendaraan.
Melalui pengujian berat jenis dan penyerapan agregat kasar dapat diperoleh nilai antara lain Berat Jenis Bulk ialah 2,58, Berat Jenis SSD ialah 2,62, berat semu ialah 2,69 dan Penyerapan Air ialah $1,60 \%$. Persyaratan Berat Jenis Bulk, Berat Jenis SSD dan Berat Jenis Semu yaitu minimal 2,5 dan untuk Penyerapan Air maksimal 3 sehingga semua hasil pengujiannya memenuhi Spesifikasi Umum Bina Marga 2018.

Melalui pengujian berat jenis dan penyerapan agregat halus dapat diperoleh nilai antara lain Berat Jenis Bulk ialah 2,57, Berat Jenis SSD ialah 2,60, berat semu ialah 2,66 dan Penyerapan Air ialah $1,32 \%$. Persyaratan Berat Jenis Bulk, Berat Jenis SSD dan Berat Jenis Semu yaitu minimal 2,5 dan untuk Penyerapan Air maksimal 3 sehingga semua hasil pengujiannya memenuhi Spesifikasi Umum Bina Marga 2018.

Hasil pengujian analisa saringan dapat dilihat pada gambar 3. Dari Gambar 3 disimpulkan bahwa gradasi agregat yang diperoleh dari analisa saringan berada diantara batas atas dan batas bawah, namun lebih mengarah ke batas bawah yang menunjukkan kurangnya persen lolos sehingga agregat dari batu Gunung Limbong Kecamatan Rantepao Kabupaten Toraja Utara yang dipakai tergolong sebagai gradasi kasar dan sesuai dengan persyaratan yang terdapat dalam Spesifikasi Umum Bina Marga 2018.

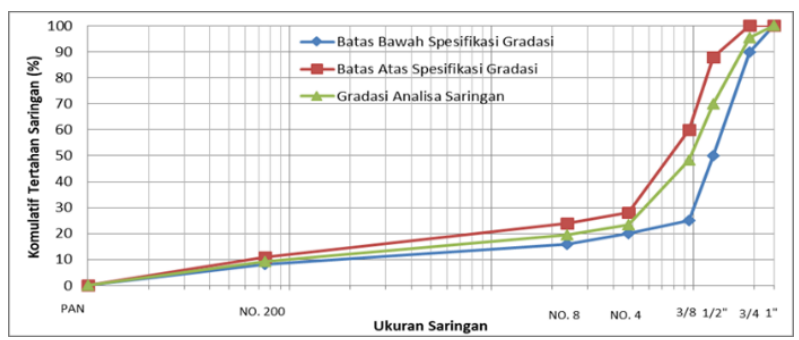

Gambar 3. Grafik analisa saringan agregat kasar dan halus

Melalui Pengujian material lolos saringan No. 200 diperoleh hasil $3,2 \%$ dan tidak melebihi nilai maksimal yang terdapat dalam Spesifikasi Umum Bina Marga 2018 yaitu 10\%. Dengan demikian, agregat dari batu Gunung Limbong Kecamatan Rantepao Kabupaten Toraja bersih dari lempung dan Ianau.

Melalui pengujian nilai setara pasir diperoleh hasil rata-rata dari 2 sampel yaitu nilai setara pasir $96,547 \%$ dan kadar lumpur 3,453\%. Dengan demikian kedua hasil tersebut memenuhi Spesifikasi Umum Bina Marga 2018 yaitu minimal $50 \%$ dan tidak terdapat Batasan atau persyaratan untuk nilai setara pasir,

Melalui pengujian partikel pipih dan lonjong agregat kasar diperoleh hasil antara lain partikel pipih yaitu 
$3,00 \%, 1,40 \%, 1,80 \%$. Dan partikel lonjong yaitu $2,30 \%, 1,30 \%, 1,60 \%$. Sesuai standar acuan Spesifikasi Umum Bina Marga 2018, nilai tersebut telah memenuhi persyaratan yaitu maksimal $5 \%$.

Melalui pengamatan secara visual kelekatan agregat terhadap aspal sebesar $>98 \%$ memenuhi sesuai spesifikasi Umum Bina Marga yaitu minimum 95\%.

\section{Berat Jenis Filler}

Batasan atau persyaratan untuk berat jenis filler tidak tercantum dalam spesifikasi Umum Bina Marga 2018. Pada penlitian ini, semen Portland sebagai bahan pengisinya (filler)

Aspal

Aspal yang digunakan dalam penelitian ini adalah aspal minyak penetrasi 60/70.

Melalui pengujian penetrasi diperoleh hasil nilai penetrasi ialah 66,7 mm. Dengan demikian, disimpulkan telah memenuhi Spesifikasi Umum Bina Marga 2018 yaitu minimal 60-70 $(0,1) \mathrm{mm}$.

Melalui pengujian titik lembek diperoleh nilai ratarata $50,2^{\circ} \mathrm{C}$. Dengan demikian, disimpulkan telah memenuhi SNI $2434-2011$ yaitu $\geq 48^{\circ} \mathrm{C}$.

Melalui pengujian Titik Nyala diperoleh nilai ratarata $290{ }^{\circ} \mathrm{C}$. Dengan demikian, disimpulkan telah memenuhi syarat yang ditentukan dalam SNI 24332011 yaitu $\geq 232^{\circ} \mathrm{C}$.

Melalui pengujian berat yang hilang diperoleh nilai rata-rata yaitu $0,434 \%$. Dengan demikian, disimpulkan telah memenuhi syarat yang ditentukan dalam SNI 06-2441-1991 yaitu $\leq 0,8 \%$.
Melalui pengujian penetrasi thin film oven test diperoleh nilai rata-rata $84,708 \%$. Dengan demikian, disimpulkan telah memenuhi syarat yang ditentukan dalam SNI 2456-2011 yaitu $\geq 54 \%$ dari penetrasi pada $25^{\circ} \mathrm{C}$.

Melalui pengujian daktilitas pada $25^{\circ} \mathrm{C}$ diperoleh nilai rata-rata $150 \mathrm{~cm}$. Dengan demikian, disimpulkan telah memenuhi syarat yang ditentukan dalam SNI 2432-2011 yaitu $\geq 100 \mathrm{~cm}$.

Melalui pengujian berat jenis diperoleh nilai ratarata $1,015 \mathrm{gr} / \mathrm{cc}$. Dengan demikian, disimpulkan telah memenuhi syarat yang ditentukan dalam Spesifikasi Bina Marga 2018 yaitu $\geq 1,0$.

\section{Marshall Konvensional}

Pada Tabel 3 berikut dapat dilihat hasil perhitungan Bulk Spesific gravity dan effective gravity.

Tabel 3. Bulk Spesific Gravity Campuran Stone Matrix Asphalt Kasar

\begin{tabular}{|c|c|c|c|c|c|}
\hline \multirow{2}{*}{$\begin{array}{l}\text { Spesific } \\
\text { Gravity }\end{array}$} & \multicolumn{5}{|c|}{ Kadar Aspal (\%) } \\
\hline & 6,00 & 6,25 & 6,50 & 6,75 & 7,00 \\
\hline $\begin{array}{l}\text { Bulk Spesific } \\
\text { Gravity } \\
\text { Agrerat }\end{array}$ & 2.79 & 2.79 & 2.80 & 2.81 & 2.82 \\
\hline $\begin{array}{l}\text { Effective } \\
\text { Spesific } \\
\text { Gravity } \\
\text { Agrerat }\end{array}$ & 2.84 & 2.85 & 2.86 & 2.86 & 2.87 \\
\hline
\end{tabular}

Melalui pengujian Marshall diperoleh karakteristik campuran Stone Matrix Asphalt (SMA) kasar dapat dilihat pada Tabel 4.

Tabel 4. Hasil pengujian karakteristik marshall campuran SMA kasar

\begin{tabular}{ccccc}
\hline $\begin{array}{c}\text { Persyaratan } \\
\text { Kadar Aspal(\%) }\end{array}$ & $\begin{array}{c}4-5(\%) \\
\text { VIM }\end{array}$ & $\begin{array}{c}\text { Min } 600(\mathrm{~kg}) \\
\text { Stabilitas }\end{array}$ & $\begin{array}{c}2-4.5(\mathrm{~mm}) \\
\text { Flow }\end{array}$ & $\begin{array}{c}\text { Min 17 }(\%) \\
\text { VMA }\end{array}$ \\
\hline 6,00 & 4,86 & 1052,06 & 3,50 & 17,66 \\
6,00 & 4,88 & 1074,93 & 3,40 & 17,68 \\
6,00 & 4,90 & 1029,19 & 3,45 & 17,69 \\
6,25 & 4,76 & 1269,34 & 3,30 & 18,16 \\
6,25 & 4,78 & 1246,46 & 3,20 & 18,17 \\
6,25 & 4,79 & 1280,77 & 3,25 & 18,19 \\
6,50 & 4,65 & 1337,95 & 2,95 & 18,65 \\
6,50 & 4,67 & 1349,38 & 3,00 & 18,67 \\
6,50 & 4,64 & 1372,25 & 2,90 & 18,64 \\
6,75 & 4,48 & 1257,90 & 3,42 & 19,09 \\
6,75 & 4,40 & 1280,77 & 3,40 & 19,02 \\
6,75 & 4,42 & 1292,21 & 3,23 & 19,03 \\
7,00 & 4,32 & 1017,76 & 3,55 & 19,53 \\
7,00 & 4,38 & 1086,37 & 3,50 & 19,59 \\
7,00 & 4,30 & 1029,19 & 3,50 & 19,52 \\
\hline
\end{tabular}


Stabilitas

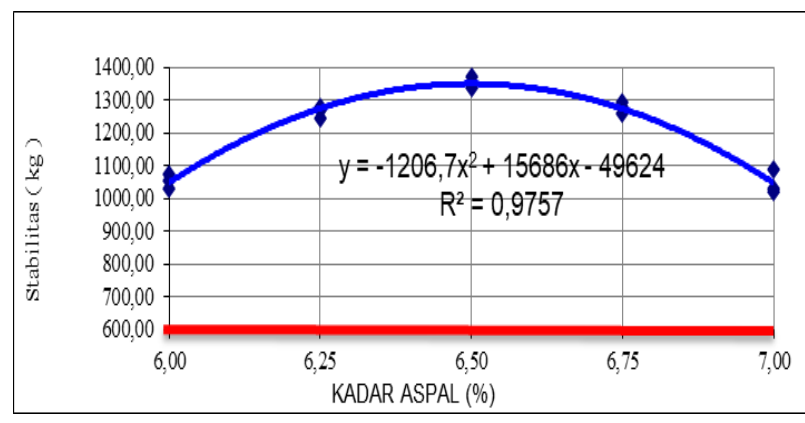

Batas minimum nilai Stabilitas yaitu $600 \mathrm{~kg}$.

Gambar 4. Hubungan antara kadar aspal dan stabilitas untuk campuran SMA kasar

Nilai Stabilitas yang diperoleh dengan penggunaan kadar aspal 6,00\% - 7,00\% untuk SMA Kasar adalah berkisar dari antara 1052,06 kg -1044,44 kg. Pada kadar aspal 6,00\%, 6,25\%, dan 6,50\% mengalami peningkatan kemudian pada kadar aspal $6,75 \%$ dan $7,00 \%$ mengalami penurunan. Berdasarkan Gambar 4 dapat disimpulkan bahwa apabila semakin sedikit kadar aspal dalam campuran SMA Kasar maka selimut aspal pada permukaan agregat akan semakin tipis sehingga menghasilkan sifat saling mengikat antar agregat menjadi lemah dan stabilitas campuran kecil, begitupun sebaliknya namun apabila aspal semakin bertambah maka selimut aspal menjadi semakin tebal sehingga sifat saling mengikat antar agregat atau stabilitas campuran kembali menurun.

\section{Void in Mix (VIM)}

Nilai VIM yang diperoleh dari penggunaan kadar aspal $6,00 \%-7,00 \%$ untuk SMA Kasar adalah antara $4,33 \%-4,88 \%$. Nilai VIM mengalami penurunan mulai dari kadar aspal $6,00 \%-7,00 \%$. Dengan demikian, semua nilai VIM dengan kadar aspal $6,00 \%-7,00 \%$ memenuhi Spesifikasi Umum Bina Marga 2018. Berdasarkan Gambar 5 dapat disimpulkan bahwa hubungan antara kadar aspal dan VIM yaitu berbanding terbalik kerena fungsi aspal ialah selaian mengikat juga mengisi rongga di dalam campuran beraspal, sehingga semakin tinggi kadar aspalnya, nilai VIM juga semakin kecil begitu juga sebaliknya, semakin rendah kadar aspalnya, nilai VIM semakin besar.

\section{Flow}

Nilai Flow yang diperoleh dengan penggunaan kadar aspal $6,00 \%-7,00 \%$ untuk SMA Kasar adalah antara $3,45 \mathrm{~mm}-3.52 \mathrm{~mm}$. Penurunan terjadi pada kadar aspal $6,00 \%,-6,50 \%$ setelah itu peningkatan terjadi pada kadar aspal $6,75 \%$. Dengan demikian, semua nilai Flow mulai dari kadar aspal 6,00\% - 7,00\% untuk SMA Kasar memenuhi Spesifikasi Umum Bina Marga 2018. Berdasarkan Gambar 6 disimpulkan semakin sedikit kadar aspal maka sifat saling mengikat antar agregat menjadi lemah sehingga kelelehan besar. Begitu juga sebaliknya. Namun apabila penggunaan aspal semakin bertambah banyak lagi maka selimut aspal menjadi lebih tebal sehingga kekuatan campurannya berkurang tetapi kelelehan meningkat, dengan kata lain kekuatan campuran/stabilitas berbanding terbalik dengan kelelehan campuran/flow.

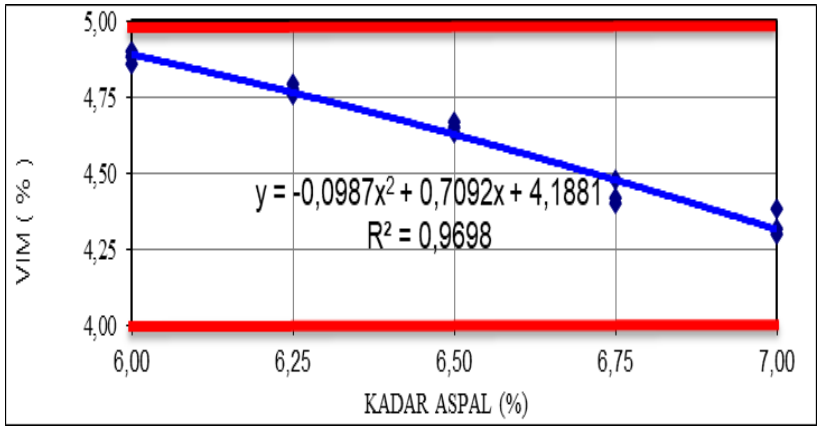

Batas minimum dan maksimum nilai VIM

Gambar 5. Hubungan antara kadar aspal dan VIM untuk campuran SMA kasar

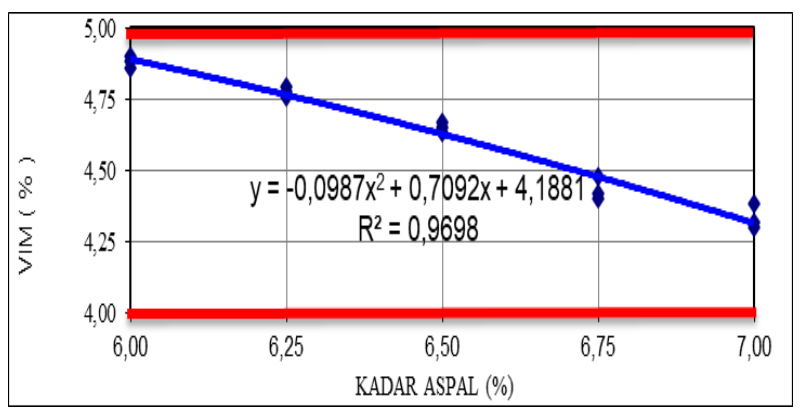

Batas minimum dan maksimum nilai Flow yaitu $2 \mathrm{~mm}$ dan $4.5 \mathrm{~mm}$.

Gambar 6. Hubungan antara kadar aspal dan kelelehan untuk campuran SMA kasar

Void in Mineral Aggregate (VMA)

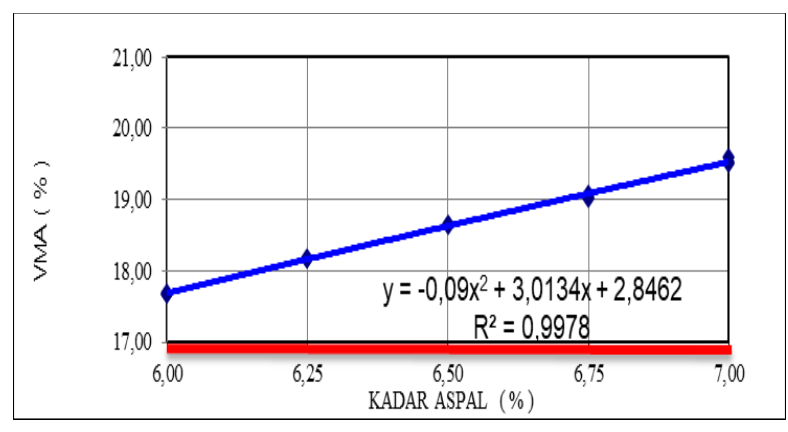

Batas minimum nilai VMA yaitu $17 \%$

Gambar 7. Hubungan antara kadar aspal dan VMA untuk campuran SMA kasar 
Nilai VMA (Rongga dalam agregat terisi aspal) yang diperoleh dengan penggunaan kadar aspal 6,00\% $7,00 \%$ untuk Stone Matrix Asphalt (SMA) Kasar adalah antara $17,68 \%-19,55 \%$. Dengan demikian disimpullakn bahwa semua nilai VMA memenuhi persyaratan dalam Spesifikasi Umum Bina Marga 2018. Dapat dilihat dari grafik bahwa peningkatan VMA terus terjadi pada kadar aspal 6,00\% - 7,00\%. Selain menyelimuti, fungsi aspal (aspal efektif) juga sebagai pengisi rongga antar agregat dan dalam partikel agregat. Dengan demikian dapat disimpulkan bahwa kadar aspal dan VMA memilikan keterkaitan yang berbanding lurus, semakin bertambah aspal yang digunakan maka rongga dalam agregat yang terisi aspal akan semakin banyak pula sehingga nilai VMA akan meningkat.

\section{Penentuan Kadar Aspal Optimum}

Kadar aspal optimum untuk campuran stone matrix asphalt (SMA) optimum ialah campuran yang memiliki nilai volumetric campuran dalam rongga (VIM) terkecil yaitu pada kadar aspal 7,00\% dan campuran merupakan campuran yang memenuhi standar spesifikasi.

\section{Stabilitas Marshall Sisa}

Stabilitas marshall sisa campuran stone matrix asphalt kasar diperoleh hasil bagi antara stabilitas campuran setelah direndam selama 24 jam dengan Stabilitas campuran yang direndam selama 0,5 jam pada suhu yang sama yaitu $60^{\circ} \mathrm{C}$.

Tabel 5. Stabilitas marshall sisa untuk stone matrix asphalt (SMA) kasar

\begin{tabular}{ccc}
\hline $\begin{array}{c}\text { Persyaratan } \\
\text { Kadar Aspal (\%) }\end{array}$ & $\begin{array}{c}\text { Min 90 } \\
\text { Stabilitas }\end{array}$ & $\begin{array}{c}\text { Stabilitas } \\
\text { Marshall } \\
\text { Sisa (\%) }\end{array}$ \\
\hline 7.00 & 1017.76 & \\
7.00 & 1086.37 & \\
7.00 & 1029.19 & \\
Rata - Rata & & \\
$\begin{array}{c}\text { Stabilitas Marshall } \\
\text { Konvensional }\end{array}$ & 1044.44 & \\
\hline 7.00 & 983.45 & 96.63 \\
7.00 & 972.01 & 89.47 \\
7.00 & 994.88 & 96.67 \\
Rata - Rata Marshall & 983.45 & 94.26 \\
Immersion & \\
\hline $\begin{array}{c}\text { Stabilitas Marshall } \\
\text { Sisa (\%) }\end{array}$ & 94.16 & \\
\hline
\end{tabular}

Melalui pengujian Marshall Immersion diperoleh hasil stabilitas marshall sisa sebesar $94,16 \%$ dengan kadar aspal 7,00\%. Nilai stabilitas marshall sisa ini telah memenuhi Spesifikasi Umum Bina Marga 2018 yaitu minimal $90 \%$.

\section{KESIMPULAN}

Karakteristik agregat yang berasal dari batu Gunung Limbong Kecamatan Rantepao Kabupaten Toraja Utara, Aspal penetrasi 60/70 dan berat jenis filler (semen) memenuhi spesifikasi umum Bina Marga 2018 dan dapat digunakan dalam campuran Stone matrix asphalt (SMA) kasar. Rancangan komposisi campuran stone matrix asphalt kasar yang menggunakan agregat dari batu Gunung Limbong Kecamatan Rantepao Kabupaten Toraja Utara diperoleh proporsi agregat kasar $72,00 \%$, agregat halus $12,50 \%$, filler $8,50 \%$ dengan kadar aspal optimum $7,00 \%$.

Nilai stabilitas marshall sisa berdasarkan hasil uji karakteristik campuran stone matrix asphalt (SMA) Kasar melalui pengujian Marshall Immersion memenuhi spesifikasi umum Bina Marga 2018.

\section{DAFTAR PUSTAKA}

[1] Adibroto, Fauna dkk. 2018. "Kinerja Marshall Immersion pada Campuran Asphalt Concrete Wearing Course (AC-WC) dengan Penambahan Cangkang Sawit sebagai Substitusi Agregat Halus".JIRS. Vol.XV. No.2.

[2] S Setiawan, D.2008." Komputerisasi Perhitungan Parameter Marshall untuk Rancangan Campuran Beton Aspal".Jurnal Teknik Sipil. Volume 4.

[3] Darlan. 2014 "Konstruksi Perkerasan Lentur (Flexible Pavement)", https://dpupr.grobogan.go.id/info/artikel/29konstruksi-perkerasan-lentur-flexible-pavement diakses pada 01 Juni pukul 17.56

[4] Kementrian Pekerjaan Umum dan Perumahan Rakyat.2018. Spesifikasi Umum Perkerasan Aspal. Pusat Litbang Prasarana Transportasi Badan Penelitian dan Pengembangan. Jakarta.

[5] Pradani, Novita., Ahmat Fatha Abdillah, dan Joy Freddy Batti, 2018. "Pengaruh Penggunaan Bahan Tambah Viatop ${ }^{66}$ Pada Campuran Stone Matrix Asphalt Terhadap Titik Lembek Aspal dan Sifat Draindown Campuran",Jurnal HPJI. Volume 4. Nomor 1.

[6] Prasetyo, A.. 2004."Lapisan dan Dukung dengan Ketebalan Berbeda", https://dspace.uii.ac.id/bitstream/handle/123456 789/3293/05.2\%20bab\%202.pdf?sequence $=5 \& \mathrm{i}$ sAllowed=y diakses pada 01 Juni Pukul 19.24

[7] Robert. Et. Al., 1996. Hot Mix Asphalt Materials, Mixture Design and Construction.NAPA Education Foundation. California. 
[8] Sukirman, S.1999. Perkerasan Lentur Jalan Raya .Nova. Bandung.

[9] Sukirman, S.2003. Beton Aspal Campuran Panas Edisi 1. Granit. Jakarta.

[10] N. Suaryana, 2015, "Evaluasi Stabilitas Dinamis dan Flow Number Sebagai Parameter ketahanan Campuran Beraspal Terhadap Deformasi Permanen. J. Pusjatan. Vol.32, No.3

[11] Wignal, Arthur.2003. Proyek Jalan Teori dan Praktek. Edisi keempat. Erlangga.

[12] Wonson K.1996. Split Mastic Asphalth The European Experience. Paper at the 1996 AAPA Pavement Indutry Conference, Asphalt Review 